\title{
Discovery of Zika Virus NS2B/NS3 Inhibitors That Prevent Mice from Life-Threatening Infection and Brain Damage
}

\author{
Antonio Coluccia, Michela Puxeddu, Marianna Nalli, Chih-Ku Wei, Yu-Hsuan Wu, Eloise Mastrangelo, \\ Tasneem Elamin, Delia Tarantino, Joachim Jakob Bugert, Benno Schreiner, Juliane Nolte, \\ Frank Schwarze, Giuseppe La Regina, Jin-Ching Lee,** and Romano Silvestri*
}

Cite This: ACS Med. Chem. Lett. 2020, 11, 1869-1874

Read Online

ACCESS

山ll Metrics \& More

Article Recommendations

Supporting Information

ABSTRACT: Zika virus (ZIKV) infection, which initially was endemic only in Africa and Asia, is rapidly spreading throughout Europe, Oceania, and the Americas. Although there have been enormous efforts, there is still no approved drug to treat ZIKV infection. Herein, we report the synthesis and biological evaluation of agents with noncompetitive mechanism of the ZIKV NS2B/ NS3 protease inhibition through the binding to an allosteric site. Compounds 1 and $\mathbf{2}$ showed potent activity in both enzymatic and cellular assays. Derivative 1 efficiently reduced the ZIKV protein synthesis and the RNA replication and prevented the mice from life-threatening infection and the brain damage caused by ZIKV infection in a ZIKV mouse model.
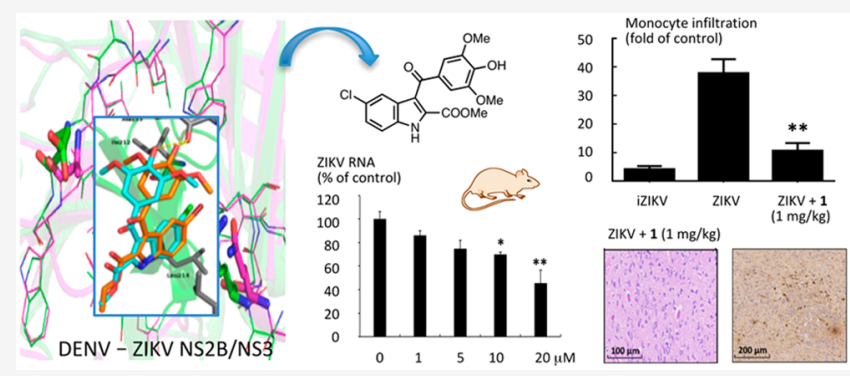

KEYWORDS: Zika, NS2B/NS3 protease, mouse model, modeling, synthesis

$\mathrm{Z}$ ika virus (ZIKV) is one of the biggest threats to global health. The WHO declared ZIKV outbreak Public Health Emergency of international concern since 2007 mainly because of the rapid spread and the sexual and vertical human-tohuman transmission. ${ }^{1}$ ZIKV is a mosquito-borne small enveloped positive single-stranded RNA virus in the Flavivirus genus and in the Flaviviridae family that is phylogenetically related to West Nile and Dengue viruses. ${ }^{2-4}$ ZIKV is transmitted to human by a vector bite during the day, primarily through the infected female Aedes aegypti, but the virus has been isolated from multiple Aedes species that are probably also involved in the transmission of ZIKV infection. ${ }^{1}$ The symptoms are generally mild. Nevertheless, ZIKV virus infection during pregnancy can cause infants with microcephaly or other inborn malformations, known as congenital ZIKV syndrome. ${ }^{5}$ The infection is also related with fetal loss and preterm birth. $^{6}$ Moreover, an increasing number of neurological complications such as Guillain-Barrè syndrome, meningoencephalitis, and myelitis have recently been reported in ZIKV-infected adults. ${ }^{7}$ The ZIKV infection was also a cause of orchitis and long-term male subfertility. ${ }^{8}$ Thus, far, there is still no specific drug or vaccine for the treatment of ZIKV infection, with only a few candidates advanced into clinical trials. ${ }^{9}$ The treatment therapies just aim to mitigate the infection symptoms. Therefore, developing new agents for prophylaxis and postinfection therapy remains an urgent challenge.
The ZIKV genome encodes a precursor protein that is processed by proteases into three structural proteins, capsid (C), premembrane/membrane (prM), and envelope glycoprotein (E), and seven nonstructural proteins (NS1, NS2A, NS2B, NS3, NS4A, NS4B, and NS5). ${ }^{10}$ The NS3 is a large multifunctional protein with two functionally distinct domains: a 176-residue $N$-terminal domain with protease activity and a 444-residue $C$-terminal domain with helicase, nucleoside $5^{\prime}$ transferase (NTPase), and 5'-terminal RNA triphosphatase (RTPase) activities. ${ }^{11}$ The NS2B polypeptide cofactor plays a key role for NS3 catalysis. ${ }^{12}$

The NS2B/NS3 protease complex is implicated in virus replication and immune system escape. Thus, it is a very attractive validated target for the development of new ZIKV proliferation inhibitors. ${ }^{13}$ The ZIKV NS2B/NS3 sequence shows high identity and folding with other flaviviral proteases, including DENV, ${ }^{14}$ but only a few data are available about the exosite. The superimposition of the DENV (PDB id 2FOM) ${ }^{15}$ and ZIKV NS2B/NS3 (PDB id 5T1 V) ${ }^{16}$ allosteric binding sites showed that several residues were conserved. Among the 20 studied residues, we observed just 2 different residues, Glu

Special Issue: Medicinal Chemistry: From Targets to
Therapies
Received: September 3, 2019
Accepted: January 15, 2020
Published: January 15, 2020


to Ala (153) and Lys to Asp (139), from the DENV to ZIKV NS2B/NS3 exosite sequence (Figure 1S, Supporting Information). In preliminary docking studies, a previously reported DENV NS2B/NS3 allosteric inhibitor, 1, and 2 (Table 1), ${ }^{17}$

Table 1. Antiviral Data vs ZIKV in HepG2 Cells ${ }^{a}$<smiles>[R]c1ccc2[nH]c([R])c([X]c3cc(OC)c(O)c(OC)c3)c2c1</smiles>

$1-13$<smiles>[R]c1ccc2[nH]c(Br)c([X]c3cc(OC)cc(OC)c3)c2c1</smiles>

14

\begin{tabular}{|c|c|c|c|c|c|}
\hline Compd & $\mathrm{R}_{1}$ & $\mathrm{R}_{2}$ & $\mathrm{X}$ & $\underset{\text { SD }}{\text { Survival } \% \pm}$ & $\begin{array}{c}\text { Viability } \% \pm \\
\text { SD }\end{array}$ \\
\hline 1 & COOMe & $\mathrm{Cl}$ & $\mathrm{C}=\mathrm{O}$ & $47 \pm 8$ & $100 \pm 14$ \\
\hline 2 & COOEt & $\mathrm{Br}$ & $\mathrm{C}=\mathrm{O}$ & $66 \pm 12$ & $100 \pm 4$ \\
\hline 3 & COOEt & $\mathrm{H}$ & $\mathrm{C}=\mathrm{O}$ & 0 & $100 \pm 2$ \\
\hline 4 & COOEt & $\mathrm{H}$ & $\mathrm{CH}_{2}$ & 0 & $100 \pm 5$ \\
\hline 5 & COOMe & $\mathrm{Br}$ & $\mathrm{C}=\mathrm{O}$ & $22 \pm 4$ & $100 \pm 7$ \\
\hline 6 & COOMe & $\mathrm{Br}$ & $\mathrm{CH}_{2}$ & $2 \pm 0.01$ & $100 \pm 6$ \\
\hline 7 & COOEt & $\mathrm{Br}$ & $\mathrm{CH}_{2}$ & $20 \pm 5$ & $100 \pm 7$ \\
\hline 8 & $\mathrm{Ph}$ & $\mathrm{Br}$ & $\mathrm{C}=\mathrm{O}$ & $23 \pm 8$ & $100 \pm 5$ \\
\hline 9 & COOMe & $\mathrm{Cl}$ & $\mathrm{CH}_{2}$ & $23 \pm 1$ & $100 \pm 3$ \\
\hline 10 & COOMe & $\mathrm{MeO}$ & $\mathrm{C}=\mathrm{O}$ & $49 \pm 6$ & $100 \pm 6$ \\
\hline 11 & COOEt & $\mathrm{MeO}$ & $\mathrm{C}=\mathrm{O}$ & $47 \pm 4$ & $100 \pm 4$ \\
\hline 12 & COOEt & $\mathrm{MeO}$ & $\mathrm{CH}_{2}$ & $28 \pm 2$ & $100 \pm 1$ \\
\hline 13 & COOEt & $\mathrm{OH}$ & $\mathrm{C}=\mathrm{O}$ & 0 & $94 \pm 4$ \\
\hline 14 & COOMe & $\mathrm{Cl}$ & $\mathrm{CH}_{2}$ & $16 \pm 1$ & $100 \pm 5$ \\
\hline $\mathrm{Riba}^{b}$ & & & & $82 \pm 6$ & $100 \pm 1$ \\
\hline
\end{tabular}

${ }^{a}$ Compounds were assayed at $10 \mu \mathrm{M}$. 1: $\mathrm{IC}_{50}=13.7 \pm 2.7 \mu \mathrm{M} ; 2$ : $\mathrm{IC}_{50}=15.8 \pm 0.9 \mu \mathrm{M}$. Experiments were performed in triplicate. ${ }^{b}$ Ribavirin was at $100 \mu \mathrm{M}$.

highlighted a consistent binding mode with the two studied NS2B/NS3 structures. Notably, 1 and 2 did not show any interactions with the 2 mutated residues. Therefore, we synthesized a small compound library and evaluated it in ZIKV-infected HepG2 cells (Table 1). Compounds 1-14 were synthesized according to Scheme 1 by Friedel-Crafts reaction of an appropriate indole with 3,5-dimethoxy-4-hydroxybenzoyl chloride or 3,5-dimethoxybenzoyl chloride in the presence of anhydrous aluminum chloride by heating at reflux overnight in dichloroethane or, alternatively, by microwave irradiation in a

Scheme 1. Synthesis of $1-14^{a, b}$<smiles>[R]c1ccc2[nH]c([R])cc2c1</smiles><smiles>COc1cc(C(=O)Cl)cc(OC)c1Br</smiles>
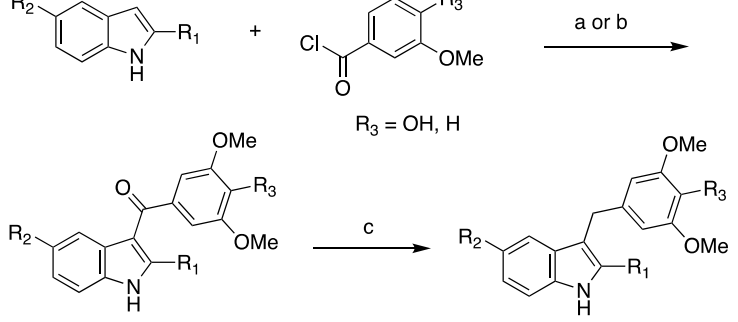

$1-3,5,8,10,11,13,15$

${ }^{a}$ 1-14: see Table $1 ;$ 15: $\mathrm{R}_{1}=$ COOMe, $\mathrm{R}_{2}=\mathrm{Cl}, \mathrm{R}_{3}=\mathrm{H}$. ${ }^{b}$ Reagents and conditions: (a) (i) $\mathrm{AlCl}_{3}$ (2 equiv), EDC, $0{ }^{\circ} \mathrm{C}$; (ii) $25^{\circ} \mathrm{C}, 30$ min; (iii) reflux, overnight; (b) $\mathrm{AlCl}_{3}$ (2 equiv), EDC, MW, closed vessel, $250 \mathrm{~W}, 100^{\circ} \mathrm{C}, 1-6 \mathrm{~min}$; (c) $\mathbf{1}-\mathbf{3}, \mathbf{5}, \mathbf{1 1}, \mathbf{1 5}$ : (i) $\mathrm{SiEt}_{3}$, TFA, 0 ${ }^{\circ} \mathrm{C}$; (ii) $25{ }^{\circ} \mathrm{C}, 48 \mathrm{~h}$.

closed vessel at $250 \mathrm{~W}$ and $100{ }^{\circ} \mathrm{C}$ for $6 \mathrm{~min}$. Methylene compounds were obtained by reduction of the carbonyl group with triethylsilane in trifluoroacetic acid by stirring for $48 \mathrm{~h}$ at $25{ }^{\circ} \mathrm{C}$. The experimental procedures are reported in the Supporting Information.

All compounds, except 13, were nontoxic at $10 \mu \mathrm{M}$ in HepG2 (liver) cells. The best ranking by activity/survival vs ZIKV virus in percent of mock was 2 (66\%), 10 (49\%), 1 (47\%), and 11 (47\%). Ribavirin protected over $80 \%$ of HepG2 cells in the presence of ZIKA-U at a concentration of $100 \mu \mathrm{M}$. The SAR summary for the inhibition of ZIKV in HepG2 cells by compounds $\mathbf{1 - 1 4}$ is shown in Chart $1 S$ of the Supporting Information.

Analyses of the binding mode of $\mathbf{1}$ and $\mathbf{2}$ at the ZIKV NS2B/ NS3 exosite highlighted (i) an $\mathrm{H}$-bond of the 4-OH with Ala152 and hydrophobic contacts of (ii) the 3,5-dimethoxy groups with Trp148, Leu150, and Ile212, (iii) the indole ring with Leu141 and Leu214, and (iv) the ester moiety close to Ile188 (Figure 1). Compounds 1 and 2 formed a strong $\mathrm{H}$ -

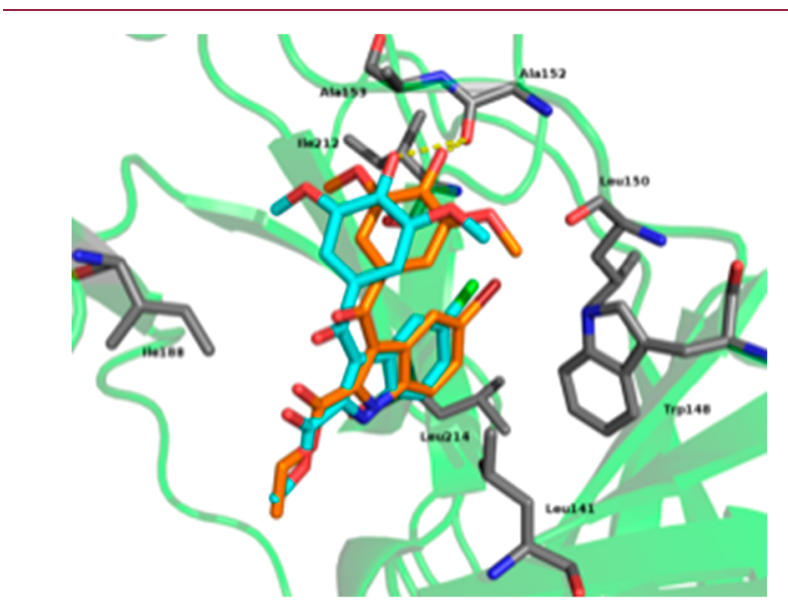

Figure 1. Proposed binding mode for 1 (cyan) and $\mathbf{2}$ (orange). Residues involved in interactions are reported as gray stick. H-bond is reported as a yellow dotted line. NS2B/NS3 is shown as a green cartoon.

bond with Ala152, also thanks to the presence of the carbonyl group. On the contrary, the 3,5-dimethoxyphenyl group of 14, deprived of the 4-OH group, lacked the interaction with Ala151 and adopted a different pose in the binding pocket (data not shown). Compounds 1, 2, and 14 as a negative control, were evaluated as inhibitors of the ZIKV NS2B/NS3 protease and in ZIKV-infected Huh7 cells (Table 2). The activity of recombinant ZIKV protease was measured through a FRET assay, using as substrate the Bz-nKRR-MCA peptide that generates a fluorescence signal when AMC is cleaved by

Table 2. Activity against ZIKV NS2/NS3 Protease

$\begin{array}{ccc}\text { Compd } & \begin{array}{c}\text { ZIKV Protease } \mathrm{IC}_{50} \pm \mathrm{SD} \\ (\mu \mathrm{M})^{a}\end{array} & \begin{array}{c}\text { Huh-7 cells } \mathrm{EC}_{50} \pm \mathrm{SD} \\ (\mu \mathrm{MM})^{b}\end{array} \\ \mathbf{1}^{c} & 158 \pm 25 & 13.9 \pm 1.1 \\ \mathbf{2} & 33 \pm 7 & 16.2 \pm 0.6 \\ \mathbf{1 4} & 770 \pm 210 & \text { nd }\end{array}$

${ }^{a}$ Activity of recombinant ZIKV protease measured through FRET assay. ${ }^{b}$ Anti-ZIKV activity in Huh-7 infected cells line. ${ }^{c}$ Under the same assay conditions, 1 inhibited the DENV2 protease with $\mathrm{IC}_{50}$ of $112 \mu \mathrm{M}$. 
the protease. ${ }^{18}$ Half maximal inhibitory concentration $\left(\mathrm{IC}_{50}\right)$ was measured through activity assays, keeping the substrate $(10 \mu \mathrm{M})$ and the protein $(25 \mathrm{nM})$ in constant concentration, while using different concentrations of inhibitors.

Compounds 1 and 2 showed $\mathrm{IC}_{50}$ values of $158 \mu \mathrm{M}$ and 33 $\mu \mathrm{M}$, respectively. Compound 14 showed an $\mathrm{IC}_{50}$ of $773 \mu \mathrm{M}$. It should be noted that, although we used very high concentrations of 14 (up to $500 \mu \mathrm{M}$ ), this compound did not completely inhibit the ZIKV protease (data not shown), thus it was removed from further analysis.

Enzyme kinetics was used to determine the mechanism of inhibition of the selected compounds, mainly 1 and 2 . We used two inhibitor concentrations that flank the $\mathrm{IC}_{50}$ value $(150 \mu \mathrm{M}$ and $250 \mu \mathrm{M}$ for $1 ; 15 \mu \mathrm{M}$ and $60 \mu \mathrm{M}$ for 2) with different substrate concentrations, keeping ZIKV protease constant to $25 \mathrm{nM}$. This experiment was done in triplicate. For both compounds, the kinetic experiments showed noncompetitive inhibition, with $K_{\mathrm{i}}$ value of $280 \pm 30 \mu \mathrm{M}$ for 1 (Figure 2) and
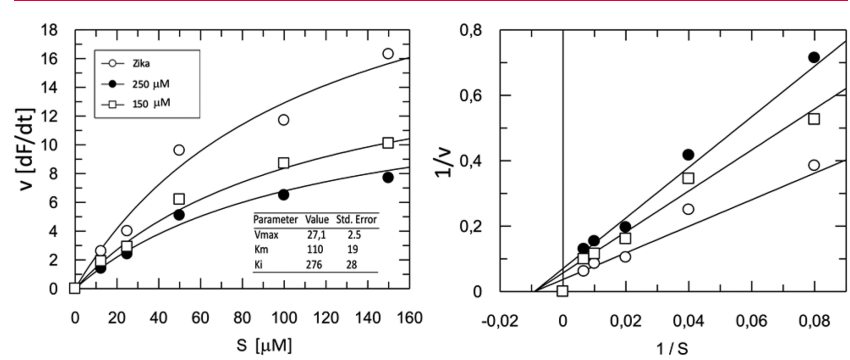

Figure 2. Enzyme kinetic experiments. Left panel: activity of ZIKV protease alone and with addition of inhibitor 1 . The text box shows the calculated $V_{\max }, K_{\mathrm{m}}$ and $K_{\mathrm{i}}$ parameters. Right panel: LineweaverBurk double reciprocal plot evidencing the noncompetitive inhibition mechanism of ZIKV protease by $\mathbf{1}$.

about $48 \pm 6 \mu \mathrm{M}$ for 2 (not shown). Microscale thermophoresis (MST) experiments were used to estimate the binding affinity of ZIKV protease to the two selected inhibitors $\mathbf{1}$ and $\mathbf{2}$. The purified ZIKV protein was fluorescently labeled using maleimide dye that binds to the sulfhydryl group and is titrated with different concentrations of inhibitors. Compound 2 showed a $K_{\mathrm{d}}$ of about $300 \mu \mathrm{M}$ while 1 exhibited lower binding affinity, estimated to be higher than 1 $\mathrm{mM}$. The values of $K_{\mathrm{d}}$ refer to the binding of the protein to the ligand in conditions of "nonprotease activity". Such high $K_{\mathrm{d}}$ values may be due to the ability of the compounds to interact tightly with the protein during its activity, i.e., when it is involved in the ternary complex formation (protein-peptideinhibitor).

Compounds $\mathbf{1}$ and $\mathbf{2}$ were predicted to have a good oral absorption according to both Lipinski's rule of five ${ }^{19}$ and Veber's rules $^{20}$ (Table 1S, Supporting Information). The Pfizer $3 / 75$ rule $(\text { tPSA }<75 \text { and } \log P>3)^{21}$ predicted that compound 2 would have higher likelihood of a preclinical toxicity event and experimental promiscuity than compound $\mathbf{1}$.

To investigate whether compound 1 exhibits anti-ZIKV activity, we treated the ZIKV-infected Huh-7 cells with various drug concentrations for 3 days. Western blotting and qRTPCR were used to measure ZIKV protein synthesis and RNA replication, respectively. Compound 1 dose-dependently reduced ZIKV protein (Figure 3, top panel) and RNA (bottom panel) levels, with $\mathrm{IC}_{50}$ value of $13.9 \pm 0.4 \mu \mathrm{M}$ against ZIKV RNA replication. Moreover, 1 did not show cell
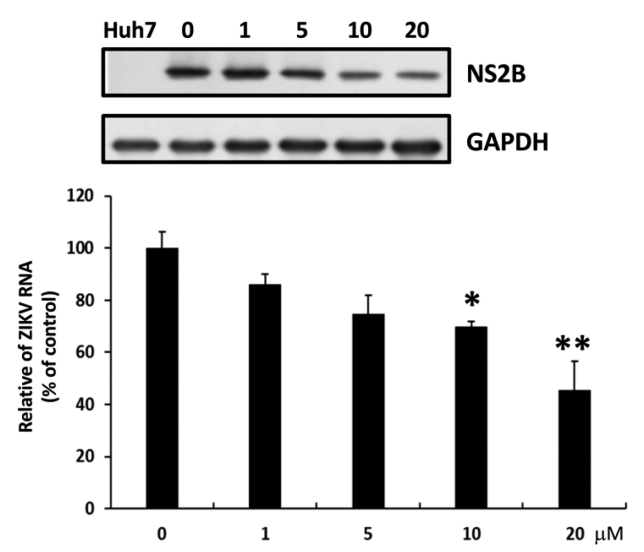

Figure 3. Top panel: compound 1 efficiently reduces ZIKV protein synthesis. Bottom panel: compound $\mathbf{1}$ inhibits RNA replication.

cytotoxicity at effective antiviral concentrations (data not shown).

6-Day-old ICR suckling mice were injected with $10^{4} \mathrm{PFU}$ of ZIKV and compound 1 ( $1 \mathrm{mg} / \mathrm{kg})$ by intraperitoneal injection at 1,3 , and 5 days post infection (dpi). Mice injected with heat-inactivated ZIKV (iZIKV) were used as mock control. The results of changes in viral titers (Figure 4), body weight, clinical scores, and survival rates (Figure 5S-7S, Supporting Information) revealed that compound 1 prevented the mice from life-threatening ZIKV infection.

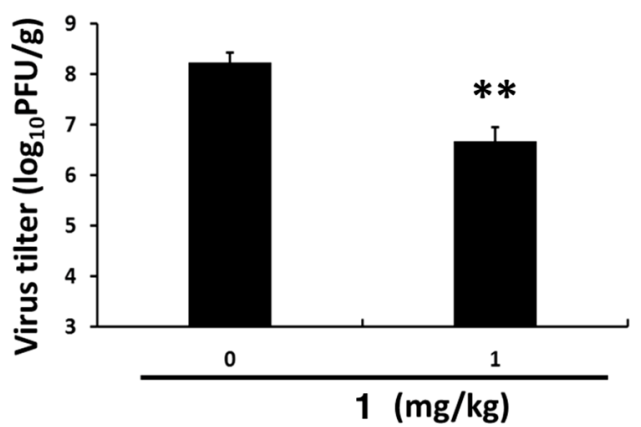

Figure 4. Life-threatening ZIKV infection with compound 1. Brain tissues were collected at the end of the day to analyze viral titer. Each group $(N=6)$ of the 6-day-old ICR suckling mice was intraperitoneally injected with $10^{4} \mathrm{PFU}$ ZIKV and $1 \mathrm{mg} / \mathrm{kg}$ of 1 at 1,3 , and 5 dpi.

ZIKV infection has been associated with severe neurological complications, with a remarkable increase in cases of GuillainBarré syndrome and of microcephaly in newborns and fetuses. $^{22-24}$ There is an unmet demand for safe drugs able to reach the main ZIKV targets by crossing the blood-brain and the placental barriers. The brain tissues were collected and subjected to hematoxylin and eosin ( $H \& E$ ) staining and immunohistochemistry (IHC) assay using anti-ZIKV NS1 antibody. The results revealed that compound 1 prevented the brain damage caused by ZIKV infection (Figure 5, top panel) and also significantly inhibited ZIKV replication in the brain tissue (Figure 5, bottom panel). To quantify monocyte infiltration, we performed an IHC assay using anti-Ly6C antibody, a monocytic marker. As presented in Figures 6 and $8 \mathrm{~S}$ in the Supporting Information, monocyte infiltration caused by ZIKV was significantly reduced by $\mathbf{1}$, indicating the 

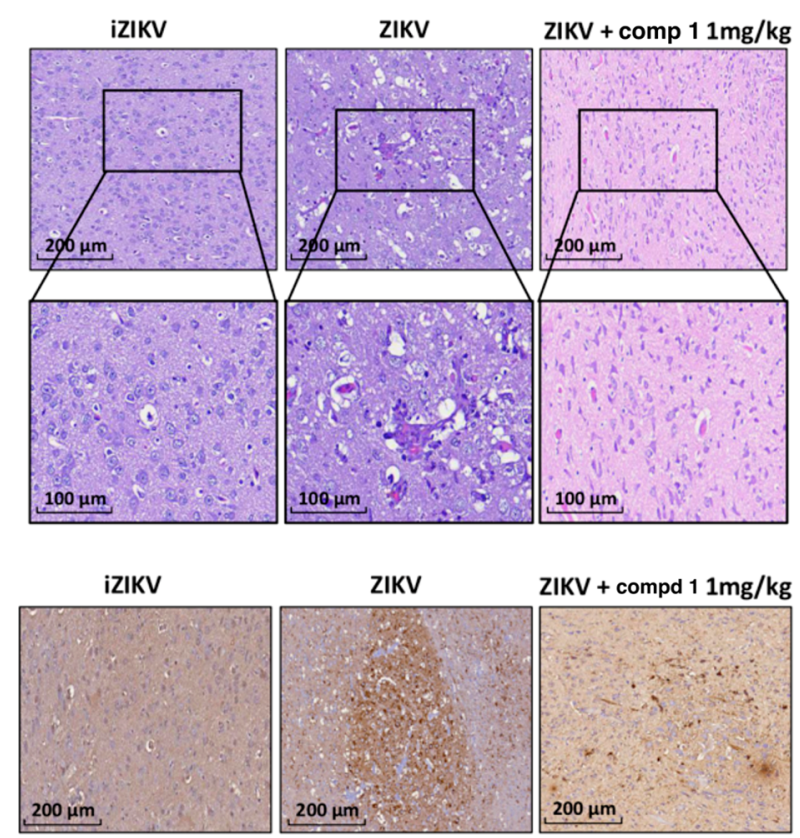

Figure 5. Activity of $\mathbf{1}$ in ZIKV infected brain tissue. Top panel: $\mathbf{1}$ prevented the brain damage caused by ZIKV infection. Bottom panel: $\mathbf{1}$ inhibited ZIKV replication in the brain tissue.

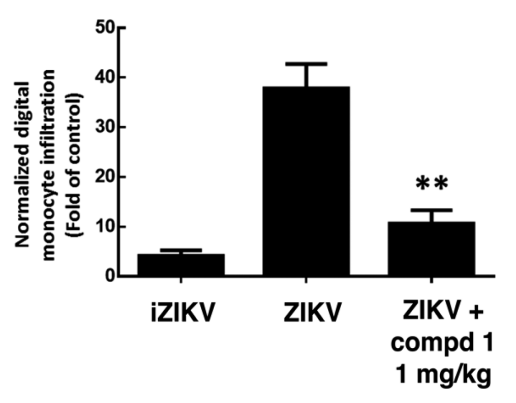

Figure 6. Reduction of monocyte infiltration caused by ZIKV.

potential of $\mathbf{1}$ against neurological disorders caused by ZIKV infection.

In conclusion, new ZIKV NS2B/NS3 protease inhibitors have been synthesized with potent activity in both enzymatic and cellular assays. The noncompetitive mechanism of the NS2B/NS3 inhibition through the binding to an allosteric site was confirmed by the enzyme kinetics experiments. Derivative 1 efficiently reduced the ZIKV protein synthesis and the RNA replication. As a proof of concept, compound 1 was evaluated in a mouse animal model. This compound was able to prevent the mice from life-threatening and the brain damage caused by ZIKV infection. These results pave the way to obtain new ZIKV drug candidates able to cross the blood-brain barrier to reach the neural cells.

\section{ASSOCIATED CONTENT}

\section{SI Supporting Information}

The Supporting Information is available free of charge at https://pubs.acs.org/doi/10.1021/acsmedchemlett.9b00405.

Additional information for experimental procedures of synthesis, computational studies, antiviral and cytotoxicity assay, NS2-NS3 protease inhibition, microscale thermophoresis, and animal model assay (PDF)

\section{AUTHOR INFORMATION}

\section{Corresponding Authors}

Jin-Ching Lee - Department of Biotechnology, College of Life Science, PhD Program in Life Sciences, College of Life Science, Department of Medical Research, Kaohsiung Medical University Hospital, Graduate Institute of Medicine, College of Medicine, and Drug Development and Value Creation Research Center, Kaohsiung Medical University, Kaohsiung, Taiwan; Phone: +88 6 7-3121101; Email: jclee@kmu.edu.tw; Fax: +88 63125339

Romano Silvestri - Laboratory Affiliated to Institute Pasteur Italy - Cenci Bolognetti Foundation, Department of Drug Chemistry and Technologies, Sapienza University of Rome, I00185 Rome, Italy; 이이.org/0000-0003-2489-0178; Phone: +39 064991 3800; Email: romano.silvestri@ uniroma1.it; Fax: +390649913133

\section{Authors}

Antonio Coluccia - Laboratory Affiliated to Institute Pasteur Italy - Cenci Bolognetti Foundation, Department of Drug Chemistry and Technologies, Sapienza University of Rome, I00185 Rome, Italy; 이이. orcidorg/0000-0002-7940-8206

Michela Puxeddu - Laboratory Affiliated to Institute Pasteur Italy - Cenci Bolognetti Foundation, Department of Drug Chemistry and Technologies, Sapienza University of Rome, I00185 Rome, Italy

Marianna Nalli - Laboratory Affiliated to Institute Pasteur Italy - Cenci Bolognetti Foundation, Department of Drug Chemistry and Technologies, Sapienza University of Rome, I-00185 Rome, Italy

Chih-Ku Wei - Department of Biotechnology, College of Life Science, Kaohsiung Medical University, Kaohsiung, Taiwan

Yu-Hsuan Wu - Institute of Basic Medical Sciences, College of Medicine, National Cheng Kung University, Tainan, Taiwan

Eloise Mastrangelo - Biophysics Institute, National Research Council, I-20133 Milano, Italy; Department of Biosciences, Università di Milano, I-20133 Milano, Italy; ㅇo orcid.org/ 0000-0002-5968-8386

Tasneem Elamin - Department of Biosciences, Università di Milano, I-20133 Milano, Italy

\#Delia Tarantino - Biophysics Institute, National Research Council, I-20133 Milano, Italy; Department of Biosciences, Università di Milano, I-20133 Milano, Italy

Joachim Jakob Bugert - Bundeswehr Institute of Microbiology, Munich, Germany

Benno Schreiner - Bundeswehr Institute of Microbiology, Munich, Germany

Juliane Nolte - Bundeswehr Institute of Microbiology, Munich, Germany

Frank Schwarze - Bundeswehr Institute of Microbiology, Munich, Germany

Giuseppe La Regina - Laboratory Affiliated to Institute Pasteur Italy - Cenci Bolognetti Foundation, Department of Drug Chemistry and Technologies, Sapienza University of Rome, I00185 Rome, Italy; (1) orcid.org/0000-0003-3252-1161

Complete contact information is available at:

https://pubs.acs.org/10.1021/acsmedchemlett.9b00405

\section{Author Contributions}

A.C.: computational studies; M.P., M.N., G.L.R.: chemical synthesis; E.M., T.M., D.T.: NS2-NS3 protease inhibition and microscale thermophoresis; J.J.B., B.S. (temporarily at TUM), 
J.N., F.S.: in vitro antiviral and cytotoxicity assay; C.-K.W., Y.M.W., J.-C.L.: anti-ZIKV activity assay in animal model.

\section{Funding}

This work was supported by Institute Pasteur Italy, (R.S., grant 2012), Italian Ministry of Education, Universities and Research, Dipartimenti di Eccellenza, grant n. L. 232/2016 (A.C., M.P., M.N., G.L.R., and R.S), Italian Government Project SIR (grant n. RBSI14C78S) (E.M.), Ministry of Science and Technology of Taiwan (grant n. MOST107-2311B-037-005-MY3), and Kaohsiung Medical University (grant n. KMU-DK108010). InstMikroBioBw: Biological evaluation of antiviral compounds - Project \# 59-2016-01.

\section{Notes}

The authors declare no competing financial interest.

\#Deceased on August 14, 2019.

\section{ACKNOWLEDGMENTS}

E.M. is thankful to Michela Bollati for support in protein expression and purification trials. J.-C.L. appreciates Charles Rice (Rockefeller University and Aapth, LCC, USA) for sharing Huh-7 cells.

\section{ABBREVIATIONS}

ZIKV: Zika virus; DENV: Dengue virus; EDC: dichloroethane; ZIKV-U: 976 Uganda strain.

\section{REFERENCES}

(1) Paixao, E. S.; Barreto, F.; da Gloria Teixeira, M.; da Conceicao, N. C. M.; Rodrigues, L. C. History, epidemiology, and clinical manifestations of Zika: a systematic review. Am. J. Public Health 2016, 106, 606-612.

(2) Wilder-Smith, A.; Ooi, E. E.; Horstick, O.; Wills, B. Dengue. Lancet 2019, 393, 350-363.

(3) Gould, E. A.; Solomon, T. Pathogenic flaviviruses. Lancet 2008, 371, 500-509.

(4) Arzuza-Ortega, L.; Polo, A.; Perez-Tatis, G.; Lopez-Garcia, H.; Parra, E.; Pardo-Herrera, L. C.; Rico-Turca, A. M.; Villamil-Gomez, W.; Rodriguez-Morales, A. J. Fatal sickle cell disease and Zika virus infection in girl from Colombia. Emerging Infect. Dis. 2016, 22, 925927.

(5) WHO. WHO statement on the first meeting of the International Health Regulations (2005) (IHR 2005) Emergency Committee on Zika virus and observed increase in neurological disorders and neonatal malformations. 1 February 2016 Statement. https://www. who.int. Accessed on 23-Nov-2019.

(6) Azevedo, R. S.; Araujo, M. T.; Martins Filho, A. J.; Oliveira, C. S.; Nunes, B. T.; Cruz, A. C.; Nascimento, A. G.; Medeiros, R. C.; Caldas, C. A.; Araujo, F. C.; Quaresma, J. A.; Vasconcelos, B. C.; Queiroz, M. G.; da Rosa, E. S.; Henriques, D. F.; Silva, E. V.; Chiang, J. O.; Martins, L. C.; Medeiros, D. B.; Lima, J. A.; Nunes, M. R.; Cardoso, J. F.; Silva, S. P.; Shi, P. Y.; Tesh, R. B.; Rodrigues, S. G.; Vasconcelos, P. F. Zika virus epidemic in Brazil. I. Fatal disease in adults: clinical and laboratorial aspects. J. Clin. Virol. 2016, 85, 56-64.

(7) Cao-Lormeau, V. M.; Blake, A.; Mons, S.; Lastère, S.; Roche, C.; Vanhomwegen, J.; Dub, T.; Baudouin, L.; Teissier, A.; Larre, P.; Vial, A. L.; Decam, C.; Choumet, V.; Halstead, S. K.; Willison, H. J.; Musset, L.; Manuguerra, J. C.; Despres, P.; Fournier, E.; Mallet, H. P.; Musso, D.; Fontanet, A.; Neil, J.; Ghawché, F. Guillain-Barré Syndrome outbreak associated with Zika virus infection in French Polynesia: a case-control study. Lancet 2016, 387, 1531-1539.

(8) Chan, J. F.; Zhang, A. J.; Chan, F. S.; Yip, C. C.; Mak, W. W.; Zhu, H.; Poon, V. K.; Tee, K. M.; Zhu, Z.; Cai, J. P.; Tsang, J. O.; Chik, K. K.; Yin, F.; Chan Kok, K. H.; Jin, D. Y.; Au-Yeung, R. K.; Yuen, K. Y. Zika virus infection in dexamethasone immunosuppressed mice demonstrating disseminated infection with multiorgan involve- ment including orchitis effectively treated by recombinant type I interferons. EBioMedicine 2016, 14, 112-122.

(9) Baz, M.; Boivin, G. Antiviral Agents in Development for Zika Virus Infections. Pharmaceuticals 2019, 12, 101-115.

(10) Pierson, T. C., Diamond, M. S. Flaviviruses. In Fields Virology, 6th ed.; Knipe, D. M., Howley, P. M., Eds.; Wolters Kluwer/ Lippincott Williams and Wilkins: Philadelphia, USA, 2013; pp 747794.

(11) Decroly, E.; Ferron, F.; Lescar, J.; Canard, B. Conventional and unconventional mechanisms for capping viral mRNA. Nat. Rev. Microbiol. 2012, 10, 51-65.

(12) Gupta, G.; Lim, L.; Song, J. NMR and MD studies reveal that the isolated Dengue NS3 protease is an intrinsically disordered chymotrypsin fold which absolutely requests NS2B for correct folding and functional dynamics. PLoS One 2015, 10, No. e0134823.

(13) Luo, D.; Vasudevan, S. G.; Lescar, J. The flavivirus NS2B-NS3 protease-helicase as a target for antiviral drug development. Antiviral Res. 2015, 118, 148-158.

(14) Shiryaev, S. A.; Farhy, C.; Pinto, A.; Huang, C. T.; Simonetti, N.; Elong Ngono, A.; Dewing, A.; Shresta, S.; Pinkerton, A. B.; Cieplak, P.; Strongin, V. A.; Terskikha, V. Characterization of the Zika virus two-component NS2B-NS3 protease and structure-assisted identification of allosteric small-molecule antagonists. Antiviral Res. 2017, 143, 218-229.

(15) Erbel, P.; Schiering, N.; D’Arcy, A.; Renatus, M.; Kroemer, M.; Lim, S. P.; Yin, Z.; Keller, T. H.; Vasudevan, S. G.; Hommel, U. Structural basis for the activation of flaviviral NS3 proteases from Dengue and West Nile virus. Nat. Struct. Mol. Biol. 2006, 13, 372373.

(16) Nocadello, S.; Light, S. H.; Minasov, G.; Shuvalova, L. A.; Cardona-Correa, A. A.; Ojeda, L.; Vargas, J.; Johnson, M. E.; Lee, H.; Anderson, W. F. Crystal structure of Zika virus NS2B-NS3 protease in apo-form. Protein Data Bank, http://www.rcsb.org/pdb/, data released 09-07-2016. Accessed on 01 July 2019.

(17) Pelliccia, S.; Wu, Y.-H.; Coluccia, A.; La Regina, R.; Tseng, C.K.; Famiglini, V.; Masci, D.; Hiscott, J.; Lee, J.-C.; Silvestri, R. Inhibition of dengue virus replication by novel inhibitors of RNAdependent RNA polymerase and protease activities. J. Enzyme Inhib. Med. Chem. 2017, 32, 1091-1101.

(18) Ulanday, G. E.; Okamoto, K.; Morita, K. Development and utility of an in vitro, fluorescence-based assay for the discovery of novel compounds against dengue 2 viral protease. Trop. Med. Health 2016, 44 (22), 1-10.

(19) Lipinski, C. A.; Lombardo, F.; Dominy, C. A.; Feeney, P. J. Experimental and computational approaches to estimate solubility and permeability in drug discovery and development settings. Adv. Drug Delivery Rev. 2001, 46, 3-26.

(20) Veber, D. F.; Johnson, S. R.; Cheng, H. Y.; Smith, B. R.; Ward, K. W.; Kopple, K. D. Molecular properties that influence the oral bioavailability of drug candidates. J. Med. Chem. 2002, 45, 26152623.

(21) Hughes, J. D.; Blagg, J.; Price, D. A.; Bailey, S.; Decrescenzo, G. A.; Devraj, R. V.; Ellsworth, E.; Fobian, Y. M.; Gibbs, M. E.; Gilles, R. W.; Greene, N.; Huang, E.; Krieger-Burke, T.; Loesel, J.; Wager, T.; Whiteley, L.; Zhang, Y. Physiochemical drug properties associated with in vivo toxicological outcomes. Bioorg. Med. Chem. Lett. 2008, 18, $4872-4875$.

(22) Cao-Lormeau, V. M.; Blake, A.; Mons, S.; Lastere, S.; Roche, C.; Vanhomwegen, J.; Dub, T.; Baudouin, L.; Teissier, A.; Larre, P.; Vial, A. L.; Decam, C.; Choumet, V.; Halstead, S. K.; Willison, H. J.; Musset, L.; Manuguerra, J. C.; Despres, P.; Fournier, E.; Mallet, H. P.; Musso, D.; Fontanet, A.; Neil, J.; Ghawché, F. Guillain-Barré syndrome outbreak associated with Zika virus infection in French Polynesia: a case-control study. Lancet 2016, 387, 1531-1539.

(23) Acosta-Ampudia, Y.; Monsalve, D. M.; Castillo-Medina, L. F.; Rodríguez, Y.; Pacheco, Y.; Halstead, S.; Willison, H. J.; Anaya, J. M.; Ramírez-Santana, C. Autoimmune neurological conditions associated with Zika virus infection. Front. Mol. Neurosci. 2018, 11, 116. 
(24) Rasmussen, S. A.; Jamieson, D. J.; Honein, M. A.; Petersen, L. R. Zika virus and birth defects-reviewing the evidence for casuality. $N$. Engl. J. Med. 2016, 374, 1981-1987.

\section{NOTE ADDED AFTER ASAP PUBLICATION}

This paper was published ASAP on January 21, 2020, with an incorrect surname for author Tasneem Elamin. The corrected version was reposted on January 23, 2020. 